\title{
CYCLOHEXIMIDE RESISTANT AMINO ACID INCORPORATION INTO MITOCHONDRIAL PROTEIN FROM NEUROSPORA CRASSA IN VIVO
}

\author{
W. SEBALD, A.J. SCHWAB and Th. BÜCHER \\ Institut für Physiologische Chemie und Physikalische Biochemie \\ der Universität München, München, Germany
}

Received 18 July 1969

\section{Introduction}

In experiments with flight muscle of Locusta migratoria, a cycloheximide-resistent mitochondrial protein synthesis has been demonstrated in vivo [1] . This cycloheximide resistant amino acid incorporation into fractions of mitochondrial membrane proteins separated by electrophoresis has been compared with incorporation by isolated mitochondria in vitro. Simi. lar labelling patterns have been obtained. In the present communication, these results are confirmed and extended in experiments with growing mycelia from Neurospora crassa.

\section{Methods}

Neurospora crassa wild type (strain 74 A) hyphae were grown for $18 \mathrm{hr}$ under conditions described previously [2]. For each point in figs. 1 and 2, one $50 \mathrm{ml}$ culture was taken. Mitochondria were isolated by grinding the washed hyphae mechanically between two corundum discs [8] in a sucrose medium $(0.44 \mathrm{M}$ sucrose, $1 \mathrm{mM}$ EDTA) [3] containing the unlabelled amino acids $(10 \mathrm{mM})$, which were used as labelled precursors in the experiment. The homogenate was centrifuged $10 \mathrm{~min}$ at $1,500 \times \mathrm{g}$. Mitochondria were isolated from the supernatant by centrifuging $30 \mathrm{~min}$ at $8,000 \times g$, resuspended in sucrose medium and purified by repeating both centrifugations [4]. The postmitochondrial supernatant was centrifuged for $30 \mathrm{~min}$ at $20,000 \times \mathrm{g}$ yielding the $20,000 \times \mathrm{g}$ supernatant containing ribosomal and cell sap proteins. Methods for determining specific radioactivity, pre-

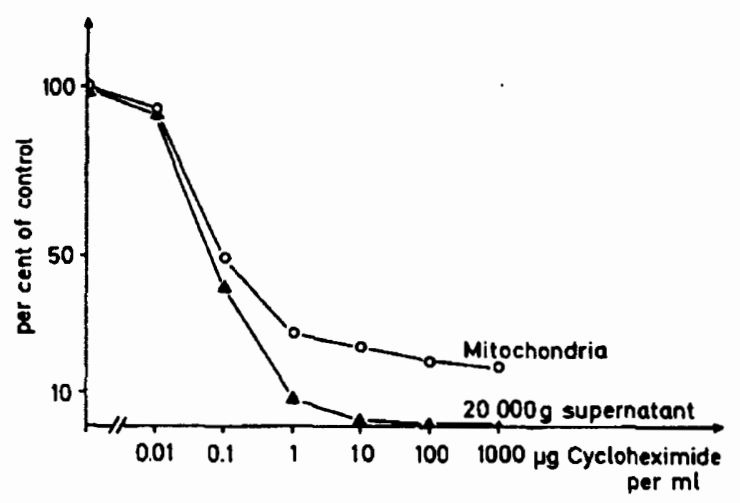

Fig. 1. In vivo incorporation of ${ }^{14} \mathrm{C}$ - $\mathrm{L}$-leucine $(10 \mathrm{nCi} / \mathrm{ml})$ into the protein of whole mitochondria $(0-0)$ and of $20,000 \times g$ supernatant $(\Delta-\Delta)$ in the presence of different concentrations of cycloheximide. The values represent percentage of control without cycloheximide. Cycloheximide was added $5 \mathrm{~min}$ prior to a $10 \mathrm{~min}$ labelling period.

paration of insoluble mitochondrial protein, electrophoretic separation and quantitative evaluation of radioactivity in the pherograms have been described [1] . Mitochondria were labelled in vitro in a medium described recently [2]. Cycloheximide was purchased from Sigma Chemical Company, and U-14C L-amino acids from the Radiochemical Centre, Amersham (leucine $305 \mathrm{mCi} / \mathrm{mmole}$, isoleucine $311 \mathrm{mCi} / \mathrm{mmole}$ and phenylalanine $459 \mathrm{mCi} / \mathrm{mmole}$ ).

\section{Results}

In the presence of $100 \mu \mathrm{g}$ cycloheximide per $\mathrm{ml}$, the radioactivity incorporated into proteins of the 


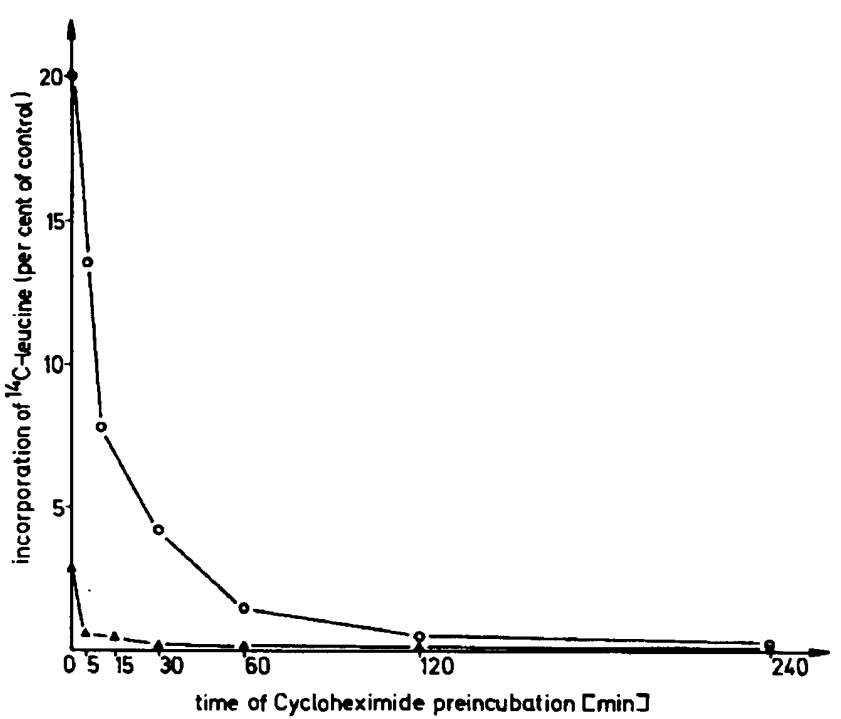

Fig. 2. In vivo incorporation of ${ }^{14} \mathrm{C}-\mathrm{L}$-leucine $(10 \mathrm{nCi} / \mathrm{ml})$ into the protein of whole mitochondria $(0-0)$ and 20,000 $X g$ supernatant $(\Delta-\Delta)$ for different times of cycloheximide preincubation $(100 \mu \mathrm{g} / \mathrm{ml})$. The values represent percentage of control without cycloheximide. The labelling period was $10 \mathrm{~min}$.

$20,000 \times g$ supernatant is less than $1 \%$ of control, but is $15-20 \%$ with whole mitochondrial protein (fig. 1). Thus, incorporation of amino acids into the proteins of the cytosol is inhibited to a higher extent than that into the mitochondrial proteins.

The radioactivity incorporatedduring a $10 \mathrm{~min}$ period decreases with increasing cycloheximide preincubation (fig. 2). However, incorporation is still observed following preincubation up to $2 \mathrm{hr}$, whereas after $4 \mathrm{hr}$ an incorporation into proteins both from the cytosol and the mitochondria is undetectable.

Mitochondria isolated from hyphae preincubated in vivo for $4 \mathrm{hr}$ with cycloheximide incorporate in vitro about $50 \%$ of the ${ }^{14} \mathrm{C}$-amino acids as compared with mitochondria isolated from untreated hyphae (fig. 3). Thus, the mitochondrial protein-synthesizing system is not irreversibly damaged following even prolonged cycloheximide preincubation. In the experiments shown in fig. 3, $5 \mu \mathrm{g}$ cycloheximide per ml were used. Similar results are obtained with higher concentrations.

Amino acid incorporation into extractable mitochondrial proteins is inhibited by cycloheximide to

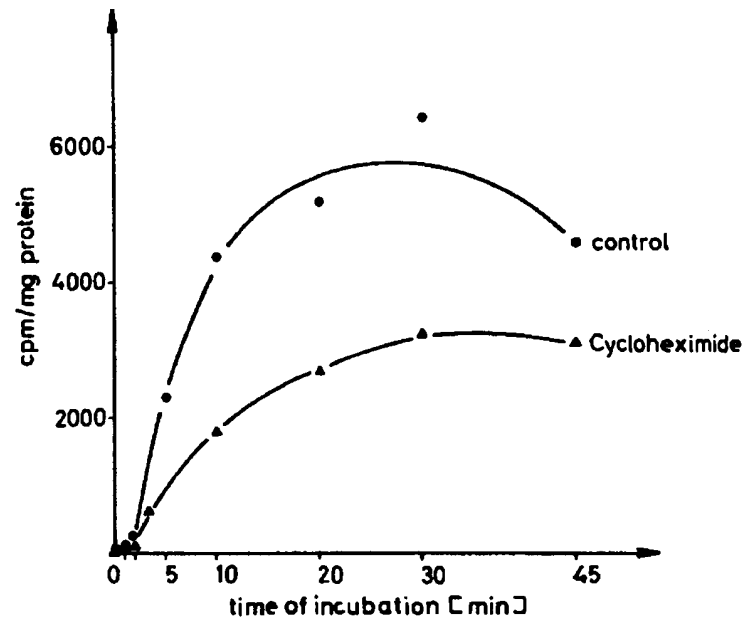

Fig. 3. Incorporation of ${ }^{14} \mathrm{C}$-L-leucine into mitochond ria in vitro. Control: mitochondria isolated from untreated hyphae. Cycloheximide: mitochondria from hyphae which were incubated for $4 \mathrm{hr}$ with cycloheximide $(5 \mathrm{\mu g} / \mathrm{ml})$ prior to isolation.

the same extent (97\%) as incorporation into proteins of the cytosol. Cycloheximide-resistant incorporation is found almost exclusively in the mitochondrial membrane proteins. This fraction still shows a specific radioactivity of $40 \%$ of the control (table 1 ).

The electrophoret ic separation of mitochondrial membrane proteins (fig. 4) indicates that the radioactivity incorporated in vivo (control) is distributed almost proportionally to the amido black staining of the individual bands. The radioactivity incorporated in vivo under cycloheximide action is found to be highest in fractions 11 and 18 , while minor radioactivity is concentrated in fractions $8,10,16$ and 23 . These fractions correspond to the protein bands 2,3 , $4,6,8$ and 10 as defined previously [2].

\section{Discussion}

A cycloheximide-resistant amino àcid incorporation into mitachondrial protein from Neurospora crassa was recently reported also by Küntzel [5]. In addition, experiments presented in this paper show that only a few fractions of mitochondrial membrane proteins are synthesized by the intrinsic mitochondrial protein synthesis in vivo, confirming the results obtained by amino acid incorporation into isolated mito- 
Table 1

Influence of cycloheximide on the in vivo incorporation of labelled amino acids into mitochondrial subfractions of Neurospora crassa. Hyphae in ten $50 \mathrm{ml}$ cultures were labelled in parallel experiments for $30 \mathrm{~min}$ with ${ }^{14} \mathrm{C}$-L-leucine and ${ }^{14} \mathrm{C}$-L-leucine and ${ }^{14} \mathrm{C}$-L-phenylalanine, each $100 \mathrm{nCi} / \mathrm{ml}$, followed by a $30 \mathrm{~min}$ chase with the corresponding unlabelled amino acids $(2 \mathrm{mM}) .5 \mathrm{cul}$ tures were preincubated with cycloheximide $(100 \mu \mathrm{g} / \mathrm{ml})$ for $5 \mathrm{~min}$.

\begin{tabular}{lllr}
\hline \multicolumn{2}{l}{$\begin{array}{l}\text { Cellular protein } \\
\text { fraction }\end{array}$} & $\begin{array}{l}\text { cpm/mg protein } \\
\text { control }\end{array}$ & With cycloheximide \\
\hline \multirow{2}{*}{$20,000 \times g$ supernatant } & 130,000 & 3,000 \\
& Whole & 120,000 & 28,000 \\
\multirow{2}{*}{ Mitochondria } & Extractable & 105,000 & $\mathbf{3 , 1 0 0}$ \\
& Residual* & 140,000 & 60,000 \\
\hline
\end{tabular}

* These fractions were used for gel electrophoresis (fig. 4).

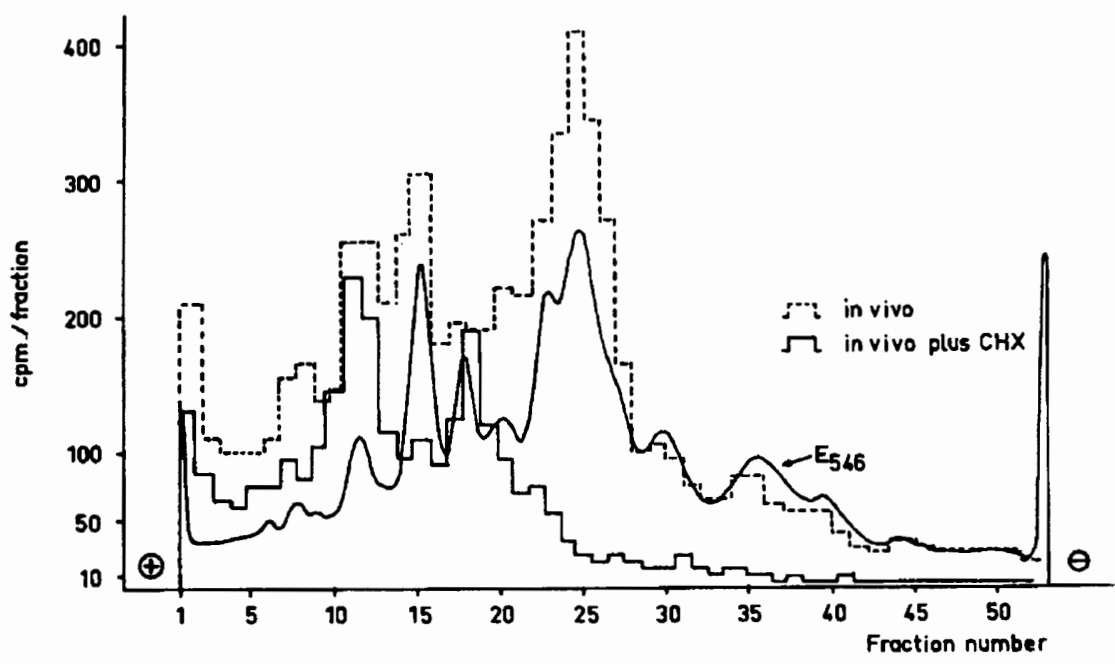

Fig. 4. Densitogram of amino black stained insoluble mitochondrial protein after gel electrophoresis (smooth line), and distribution of in vivo incorporated radioactivity (edged lines), in the presence (-) or absence (-.-) of cycloheximide (CHX) $(100 \mathrm{mg} / \mathrm{ml})$.

chondria [2]. In in vivo and in vitro experiments, after electrophoretic separation of membrane proteins, the highest specific radioactivity is found in a band of low mobility, previously called band 4 [2]. In mitochondria from flight muscle of Locusta migratoria and from Neurospora, the labelling pattern is similar, showing labelled bands nearly in the same positions after electrophoretic separation of the membrane proteins.

After the labelling of isolated mitochondria in vitro, incorporated amino acids are partially associated with mitochondrial ribosomes, as demonstrated recently by Neupert et al. [7]. This is not observed, however, when mitochondria are labelled in vivo under cyclo- heximide action followed by a 30 min chase [6]. Hence, it may be assumed that the labelling pattern obtained in vivo in the presence of cycloheximide represents. predominantly complete peptide chains.

It cannot be decided, however, if the peptide chains synthesized by the intrinsic mitochondrial system are integrated into functionally active proteins, when the extramitochondrial protein synthesis is eliminated simultaneously. This problem may be considered with experiments in vitro as well as in vivo under cycloheximide action. Nevertheless the mitochondrial protein synthesis is functioning for at least $1 \mathrm{hr}$ after the elimination of the extramitochondrial system by cyclo- 
heximide. This indicates that the two systems are not closely coupled or that the coupling is weakened by the action of the antibiotic.

The incorporation of ${ }^{14} \mathrm{C}$-leucine into mitochondrial proteins decreases with increasing cycloheximide preincubation (fig. 2). In preliminary experiments, however, an increased leucine pool was observed after inhibition of the main part of cellular protein synthesis by the antibiotic [6]. If the dilution of the added ${ }^{14} \mathrm{C}$-leucine by the pool is considered, it may be calculated that about $50 \%$ of the original mitochondrial protein synthesis persists after $45 \mathrm{~min}$ cycloheximide preincubation.

\section{Acknowledgements}

We express our sincere appreciation to Prof. Dr. F.Kaudewitz for the opportunity to work in the Institut für Genetik der Universität München and to cultivate Neurospora, and for his permanent interest in this work. We are indebted to Miss D.Hacker for valuable technical assistance. The work was supported by the Deutsche Forschungsgemeinschaft, Schwerpunktprogramm "Biochemie der Morphogenese".

\section{References}

[1] W.Sebald, Th.Hofstötter, D.Hacker and Th.Bücher, FEBS Letters 2 (1969) 177.

[2] W.Sebald, Th.Bücher, B.Olbrich and F.Kaudewitz, FEBS Letters 1 (1968) 235

[3] D.J.L.Luck, J.Cell Biol. 16 (1963) 483.

[4] J.W.Greenawalt, D.O.Hall and O.C.Wallis, in: Methods of Enzymology, vol. 10, eds. R.W.Estabrook and M.E.Pullman (A cademic Press, New York and London) pp. 142147.

[5] H.Kuntzel, Nature 222 (1969) 142.

[6] W.Sebald, A. Schwab and Th. Bücher, 20th Mosbach Kolloquium, eds. Th.Bücher and H.Sies (Springer Verlag, Heidelberg) in press.

[7] W.Neupert, W.Sebald, A.J.Schwab, P.Massinger and Th. Bücher, European J. Biochem., submitted for publication.

[8] H.Weiss, experiments to be published. 